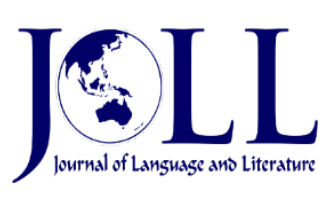

Vol. 21 No. 2, October 2021, pp. 439-452

DOI: 10.24071/joll.v21i2.3430

Available at https://e-journal.usd.ac.id/index.php/JOLL/index

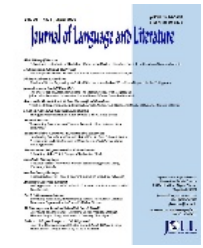

This work is licensed under a Creative Commons Attribution-ShareAlike 4.0 International License.

\title{
Negative Politeness Strategies in What Would You Do? TV Show
}

\author{
Meidiana Suyono \& Erna Andriyanti* \\ erna.andriyanti@uny.ac.id \\ English Education Department, Universitas Negeri Yogyakarta, INDONESIA
}

\begin{abstract}
Being polite is significant to maintain good communications as well as social relationship and therefore various strategies are applied to show language politeness. This sociopragmatic study deals with negative politeness strategies found in What Would You Do? TV show to explain the types and investigate the reasons of choosing those strategies. This research applied a descriptive qualitative approach supported by frequency of data occurrences. The data were in the form of utterances containing negative politeness strategies, sourced in the participants' responses to the actors of the TV show. There were 106 data collected from 39 videos in the show's YouTube channel. The trustworthiness was attained through investigator triangulation, which is the use of multiple researchers in an empirical study. The findings show that seven negative politeness strategies are used by the participants in the TV show: Be Indirect (12), Questions, Hedges (40), Minimize the Imposition (12), Apologize (25), Give Deference (9), Be Pessimistic (6), and State the FTA as General Rule (2). The dominance of Questions, Hedges relates to the options provided to the addressee to accept or refuse the speaker's request. Related to reasons, the Payoffs was dominant (with 84 occurrences) because it is the basic factor the participants might think about what they will get by applying a certain strategy. The Circumstances factor has 22 occurrences, consisting of Social Distance (14), Social Power (5), and Rank of Imposition (3). The politeness strategies in the TV show are authentic and might be utilized as learning materials for learners of English as a foreign language (EFL) to raise their awareness of politeness across languages and cultures.
\end{abstract}

Keywords: sociopragmatics; negative politeness; What Would You Do?; TV Show

\section{Introduction}

Most people want to have smooth conversations to deliver what they want or what they think and there are various ways to realize it with the least possibility of hurting others' feeling. They basically share the same perspective that respecting others is a way to 
be polite for creating positive atmosphere, being acceptable by others, and avoiding threats to one's face in communication.

Face is a self-image that we want other people to see in a certain way (Brown \& Levinson, 1987; Redmond, 2015). This image is influenced by the situation or context and the face is presented through the way we communicate and interact. There are two types of face: positive and negative (Brown \& Levinson, 1987). Positive face refers to a speaker's want to be liked, admired, and approved by others while negative face relates to desire to have freedom of action and from imposition. To be polite is to avoid or minimize face threatening acts (FTA) and can be done through verbal and non-verbal behaviors. The politeness strategies a speaker performs are called positive or negative based on the types of face $s /$ he wants to save.

Politeness is a form of respect (Brown \& Levinson, 1987; Holmes, 1995) and functions to reduce or avoid conflicts (Lakoff, 1976, Siffianou, 1992) and to create balance (Leech, 1983) in communication. Related to language politeness, there has been a large body of research conducted in different countries, discussing -among others- the strategies performed in various settings (i.e., AlAfnan, 2014; Al-Sobh, 2013; Banikalef, Maros, Aladdin and Al-Natour, 2015; Fitriyani \& Andriyanti, 2020; Jeanyfer \& Tanto, 2018; Jegarlooei \& Allami, 2018; Mu, 2015; Ramadhani, Gurning, \& Sibarani, 2014; Senowarsito, 2013), the markers (Jegarlooei \& Allami, 2018; Terkourafi, 2011), as well as its relation to culture (i.e., Haugh \& Chang, 2015; Huang, 2008; Leech, 2005) and gender (Jegarlooei \& Allami, 2018).

This present study focuses on negative politeness strategies, a topic which is rarely discussed because most scholars researching politeness strategies included both positive and negative strategies. It deals with politeness through sociopragmatics, which Leech (1983) describes as a study to reveal the pragmatic or speaker's meanings that reflect the local social conditions on a language use. The sociopragmatic factors are related to norms, which vary from culture to culture (Leech, 2005) and according to Brown and Levinson (1987), they consist of payoffs and the sociological variables: social distance, social power, and rank of imposition.

There are four types of politeness strategy: positive politeness, negative politeness, bald-on record, and off- record (Brown \& Levinson, 1987). The negative politeness is the most elaborated and the most conventionalized set of linguistic strategies for FTA redress. The negative politeness can be achieved through ten strategies: Be Conventionally Indirect; Questions, Hedges; Minimize the Imposition; Apologize; Give Deference; Be Pessimistic; Impersonalize Speaker and Hearer; State the Face Threatening Acts (FTA) as General Rule; Nominalize; and Go on Record as Incurring a Debt (Brown \& Levinson, 1987). Different from positive politeness strategies which are to satisfy addressee's desire, the point of using negative politeness strategies is to avoid offence to the addressee's face so the addressee can choose whether to agree or disagree with what the speaker asks or say.

Showing politeness through gestures and respectful speeches can be a sign that a person is aware of others' feeling and tries his best not to embarrass or make them feel uncomfortable. However, sometimes people fail at choosing appropriate politeness strategies due to some reasons, one of which is cultural. Although some gestures or expressions are understood globally, some are different and influenced by cultures. According to Lakoff in Mills (2003), for instance, the politeness and impoliteness norms in American culture is changing from a respectbased culture to becoming a camaraderie culture or being friendly and making the hearer feel good. In Brown and Levinson's (1987) theory, this tendency is viewed as moving from a "negative politeness culture" to a more "positive politeness culture".

Jeanyfer and Tanto (2018) shows that in eastern countries like Indonesia, negative politeness strategy is mostly used to communicate among the society especially to people who have more power, while a mix of both positive and negative politeness is usually used to communicate to people who have less power or such close relationships. In classroom context, Senowarsito (2013) shows that a teacher usually dominates interactions 
in the classroom by giving instructions, giving explanations, or answering students' questions. Meanwhile, the students tend to use some interpersonal function markers such as agreement, disagreement, or confirmation. Therefore, the teacher applies positive politeness strategy to engage the students in the interaction while the negative politeness strategy is used to lessen the imposition and providing options. This is in line with Holmes' (2013) statement that politeness influences the choice between different address forms and that the social dimension influences what is considered polite in different situations and communities.

Another reason of why sometimes people fail at choosing an appropriate politeness strategy is the speaker's educational background, age, and gender. Mohammadi and Tamimi Sa'd (2014) found that Iranian EFL learners' requests, as assessed by native speakers, are mostly partially (im)polite and therefore emphasize the need of instructional intervention and explicit teaching of pragmatics related to politeness. According to Mills (2003), educational background of a speaker will likely influence the use of the politeness marker in a more formal interaction. Women are more likely to apply politeness markers and speech act formulae than men (Friginal \& Hardy, 2013; Mills, 2003). Similarly, Ramadhani, Gurning, and Sibarani (2014) reveal that there are different uses of politeness strategies by male and female buyers in a traditional market.

These reasons make a slight difference of the way people approach others to engage in a conversation. Politeness strategies are therefore important to maintain a nice relationship between people in a conversation. The use of different politeness strategies shows the distance, the power, or the social difference between the speakers. Therefore, being aware of the notion of politeness and someone's background is really important to determine an appropriate strategy in an interaction to avoid losing or embarrassing other's face.

This study investigates negative politeness in What Would You Do? produced by American Broadcasting Company (ABC). It is a hidden-camera TV show, which reveals spontaneous reactions of people when they are put in situations with ethical dilemma. This natural language phenomenon is interesting to be discussed since positive politeness is assumed to be commonly used by Americans while the negative one is not. Since the TV camera is hidden and the setting of this show is mostly in public places, anyone can be the participant in the communication. There have been various people engaging in the conversations and they might give numerous examples of the use of negative politeness strategy.

This study has two objectives: 1) to explain the kinds of negative politeness strategies applied by the participants of What Would You Do? TV show; and 2) investigate the factors influencing the use of the strategies. The results of the study will contribute to a better understanding about how English speakers pragmatically select strategies to convey messages in polite ways and how social factors affect their choices.

\section{Methodology}

This descriptive qualitative study analyzes utterances which contain negative politeness used by the participants of What Would You Do? TV show. This approach was chosen because it gives a deep understanding into the meanings and functions of events (Vanderstoep \& Johnston, 2009). The results are presented in narrative or textual description of the phenomena. Frequency of data occurrences related to types and factors of negative politeness strategies is reported to support the qualitative analysis. There were 106 data taken from 39 videos in the YouTube channel of What Would You Do? TV show from late 2018 and 2019. The purpose of combining qualitative data and presenting data frequency in this present study is for complementarity (see Greene, Caracelli and Graham, 1989), that is to yield complementary insights and strengths for understanding the politeness phenomenon.

Human instrument in this research was significant due to activities of determining which utterances contained negative politeness strategies and measuring if data were saturated. A data sheet was utilized as the secondary instrument to note the selected 
utterances and used in the process of data categorization and analysis. The data were collected through watching the videos with the English captions thoroughly, note-taking, and fixing the appropriateness of the captions when necessary. After that, the captions were transcribed and identified to select the required data. The last step was categorizing the selected utterances in the data sheet.

The data were analyzed through four steps. First, the expressions containing negative politeness were highlighted. Afterwards, those expressions were classified into the types of negative politeness and the factors that possibly affected the use of those expressions were determined based on the contexts (Brown \& Levinson, 1987). Finally, the results were interpreted in accordance with Brown and Levinson (1987) and the relevant previous studies. The research credibility was gained through investigator triangulation (Denzin, 2009). The researchers and two other scholars analyzed and interpreted the data individually and any differences were discussed to reach a shared decision.

\section{Results and Discussion}

The types of the negative politeness strategies used by the participants were linked to the factors, as shown in Table 1.

Table 1. Types and factors of negative politeness strategies in What Would You Do? TV show

\begin{tabular}{|c|c|c|c|c|c|}
\hline \multirow{2}{*}{ Types } & \multicolumn{4}{|c|}{ Factors } & \multirow{2}{*}{ Total } \\
\cline { 2 - 5 } & \multirow{2}{*}{$\begin{array}{l}\text { The } \\
\text { Payoffs }\end{array}$} & $\begin{array}{c}\text { The Circumstances } \\
\text { Social } \\
\text { Distance }\end{array}$ & $\begin{array}{c}\text { Social } \\
\text { Power }\end{array}$ & $\begin{array}{c}\text { Rank of } \\
\text { Imposition }\end{array}$ & \\
\hline Be Indirect & 9 & 0 & 3 & 0 & 12 \\
\hline Questions, Hedges & 35 & 2 & 1 & 2 & 40 \\
\hline Minimize the Imposition & 12 & 0 & 0 & 0 & 12 \\
\hline Apologize & 21 & 3 & 0 & 1 & 25 \\
\hline Give Deference & 0 & 9 & 0 & 0 & 9 \\
\hline Be Pessimistic & 6 & 0 & 0 & 0 & 6 \\
\hline State the FTA as General & & & & & \\
Rule & 1 & 0 & 1 & 0 & 2 \\
\hline Total & $\mathbf{8 4}$ & $\mathbf{1 4}$ & $\mathbf{5}$ & $\mathbf{3}$ & $\mathbf{1 0 6}$ \\
\hline
\end{tabular}

Seven out of the ten negative politeness strategies were found in the data. Questions, Hedges, is the most frequently used strategy, with 40 occurrences, followed by other types with lesser frequency: Apologize, Be Indirect, Minimize the Imposition, Give Deference, Be Pessimistic, and State the FTA as General Rule. The three strategies not found in the participants' use of negative politeness strategies are Impersonalize Speaker and Hearer, Nominalize, and Go on Record as Incurring a Debt.

Table 1 also illustrates that the biggest factor of the choice of the negative politeness strategies is the Payoffs, with 84 occurrences out of 106 data. The Circumstances factors occur 22 times, with spread in social distance, social power, and rank of imposition factors.
Following are explanations with regard to the two research objectives, all of which are with representative excerpts taken from relevant videos. A refers to the actor, whose utterances serve as an adding context. P stands for participant, whose utterances contain politeness strategies.

\section{Types of negative politeness strategies in What Would You Do?}

\section{Be Indirect}

Indirect speech acts are certainly the most significant form of conventional indirectness (Brown \& Levinson, 1987). AlAfnan (2014) found that Be Indirect is mainly used both in positive and negative politeness among 
Malaysian colleagues in their workplace emails. Differently, this strategy is not the most frequently used by the participants in this present study.

The following example is from a video showing an actor pretending as a tourist who intentionally litters a city park. Some of the participants who see this action decide to stop the actor. There is a participant who spontaneously tells him that there is a trash can just near him, hoping that the actor will stop littering.

P: There's a trash can right there, you know. A: Oh, I don't care.

(Datum 12)

The participant's utterance is actually a hint for the actor. The participant intends to command the actor to put the garbage into the trash can instead of throwing it all over the park. He forms his command into a piece of information to let the actor takes the hint and does what he is supposed to do by himself. The participant does that to respect the negative face of the actor because he just met the actor in that place and does not want to embarrass him. The hint makes the actor free from imposition but at the same time tries to suggest him do the request. In return, the actor succeeds to get the message although he refuses to fulfill the participant's request.

Another application of this strategy is shown in this similar example.

P: Wow! You have dropped something, lady. A: If you guys wanna pick it up, it's fine. P: No, I want you to pick it up.

\section{(Datum 13)}

Being in the same situation illustrated in Datum 12, the participant in Datum 13 who walks behind the actor sees her continuously throw garbage as she walks by. He shows his reaction with an exclamatory word 'wow' to show his surprise of what the actor just did. He then says to the actor that she just dropped something, referring to her action of throwing the garbage in the park. He uses this strategy to indirectly notify that the actor is littering the park and to avoid embarrassing the actor's face. Despite understanding the message, she responds his utterances by saying that he can pick it up if he wants. This example shows that the participant uses hints to soften his requests to the actor since they do not know each other.

Following is another illustration of the use of indirectness by a participant in her response toward discrimination.

A: I just don't know what to do.

P: Don't worry about them. There's stupid people everywhere. Trust me.

(Datum 58)

This example was taken from a scene where a girl is discriminated for befriending by her white classmates, acted by other actors. The participant approaches the girl and makes sure that she is alright. He even tries to comfort her to ignore the bullies. He mentions 'there is stupid people everywhere', which actually points to her classmates' discriminative actions. He uses this strategy of indirectness to lessen his utterance and avoids making the other actors' lose their face.

This study shows indirectness as a negative politeness strategy among people who are not close to one another. However, being indirect is also frequently used by those who are already familiar with each other, for example as shown in teacher-student interactions in classroom (Fitriyani \& Andriyanti, 2019)

\section{Questions, Hedges}

The use of question provides option to the addressee to accept or to refuse the speaker's request to maintain the addressee's freedom of action. It can also function to avoid disagreement between speakers. While hedges are used to show that the speaker is not totally sure about something. Hedges refer to "a particle, word or phrase that modifies the degree of membership of a predicate or a noun phrase in a set; it says of that membership that it is partial or true only in certain respects, or that it is more true and complete than perhaps might be expected" (Brown \& Levinson, 1978). "I'm pretty sure I've read that book before." or "A swing is sort of a toy." are examples of hedging. 
Following example shows two female actors who try to rob a man (another actor) by pouring drug in his drink when he is in the bathroom. At the moment the participant sees what one female actor does to the drink. He chooses to keep silent and waits until the male actor comes back from the bathroom.

P: Do you know they put something in your drink?

A: I'm sorry?

P: I saw them putting something in your drink. I'll buy a new one.

(Datum 07)

When the actor is back, the participant carefully asks him whether he knows that something happens to his drink or not.

Feeling curious about the question, the actor responds to the participant by saying "I'm sorry?" to show his unawareness of what happens to his drink. As the participant already gets the attention from the actor, he continues to explain what he saw and tells him that he will buy a new drink. The use of question gives an opportunity for him to gain attention from the actor and lessen the potential face threat to the actor.

An example of the use of hedge is in the following conversation, taking place in a show store where a child wants to buy a pair of sneakers but her father could not afford it.

A: He's being stupid. He's not getting what I want.

P: That's not being stupid. Maybe he don't have it. I couldn't get Jordans and stuff like that when I was young. You're about to get some expensive sneakers. You ought to be happy. I think you should listen to Dad.

(Datum 11)

Because the child actor is rude to her father, the participant tries to stop her by voicing out his disagreement with the actor's calling her father stupid. Although he tries to opine against her statement, he considers the actor's face. He uses hedges to lessen the possibility of face threat to the actor and to make his utterances sound like an opinion rather than a disagreement. He uses 'maybe', which sounds his doubt about what really happens with the dad actor. The other hedge 'I think' is to show that he tries to give suggestion to the child actor rather than coerces the actor. By using this strategy, he expects that the child actor will listen to him and stop embarrassing her father. At the same time, he is also able to maintain the actor's face and does not make her feel intimidated.

Another example is from a scene in a restaurant, where a male black actor acts as a babysitter and is suspected of kidnapping by a female actor. She takes the man's photos and continuously investigates him. Other people in that restaurant pay attention to what the woman is doing but only some of them react to this scene. A female participant bravely confronts the woman actor and asks her to stop bothering the man actor. The female actor shows her bad feeling because she got news about a black man who is suspected as a kidnapper while he was babysitting his friends' kid.

A: It's giving me an uneasy feeling.

P: Don't you think the kids would say something if something was wrong?

(Datum 34)

By asking a question to soften her utterance, the participant tells the actor that the kids would say something if they have problems. She wants to make the woman actor understand that she should not worry too much and judges the man because he is black. She expects that the woman actor would grab the hint and stop doing her action.

Questions, Hedges strategy is most frequently used by the participants in the TV show. Most of them ask questions to communicate politely with people they do not know. Meanwhile, hedges are used by the participants to redress the possibility of being rude to the person they are talking to. Hedging is also dominantly used by one of royal family members studied by Pratiwi (2019). Interestingly, studies show that the use of hedges as face mitigating devices relates to language proficiency and gender (Jegarlooei \& Allami, 2018). 


\section{Minimize the Imposition}

"Could I have your time just for a minute?" is one example of how a speaker minimizes an imposition to the addressee. The word 'just' has the literal meaning of 'exactly' and 'only'. However, this word is used differently in the utterance and functioned to minimize the potential face threat to the addressee. The speaker may need more than a minute to talk to the addressee, however, he chooses to say that to avoid a rejection and to make the utterance less hard to fulfill. Another example is a teacher's utterance "Before we start our class today, I would like to review a little about ....", to imply that the interlocutors are not to do much (Senowarsito, 2013). Words other than just and a little that minimize imposition include a tiny, little bit, a sip, a taste, a drop, a smidgen, and a bit.

Following is how a participant minimizes an imposition towards a coach, who forces a wrestler.

P: Can I please talk to you for a second, coach to coach?

A: What's the matter?

\section{(Datum 53)}

Two actors act as a young wrestler and his coach, playing a situation in a barbershop where the wrestler is forced to cut his hair by his coach. Because the wrestler does not want to do it, they start to argue. Some of the customers in that barbershop pay attention to the quarrel, but only one of them voices out his opinion. Feeling uncomfortable with the coach forcing the wrestler, the participant initially approaches the coach and asks him to have a little conversation. He uses the words 'a second', but the actual conversation may last longer. He uses this strategy to make the least possibility of imposition to the addressee. If he does not minimize the imposition, the actor could have easily rejected his request. The use of 'a second', 'a moment' or other similar words in a request to minimize the imposition, as also stated by (Mohammadi \& Tamimi Sa'd, 2014), shows that the speaker puts himself in a solidarity, not power, relation with the interlocutor.
Another use of Minimize the Imposition strategy is in Datum 73. Two actors pretend as a customer and staff in a nail salon. The customer actor talks to her friend on the telephone, mocking the staff actor for not being able to speak English. She said that she can say anything and the staff would not understand a single word she says.

A: Can you imagine working in other's country for your life and not learning English? I can literally say anything right now and she wouldn't understand.

P: I'm a little uncomfortable. Your conversation, it's a little bit weird.

A: I'm just saying what everyone else is thinking.

(Datum 73)

Other customers seem shocked by what the actor has said and one of them tries to talk to her. She expresses her uncomfortable feeling by saying that she is 'a little' uncomfortable with the actor's conversation, which is 'a little bit' weird. She does it to save the actor's face because she does not want to offend her. At the same time, she actually wants to stop the actor's rudeness by saying that utterance.

Using Minimize the Imposition strategy, the participants in Data 53 and 73 are able to save the addressees' face. It minimizes the threat by freeing the addressees from any imposition.

\section{Apologize}

By apologizing, a speaker indicates his reluctance to impose on H's negative face and thereby partially redress that imposition. Participants who use this strategy mostly apply it to begin their utterances before continuing to deliver their opinion. They also use it to show their sympathy towards the actors. They use apology when they emphasize that they feel sorry for intervening someone's business.

Following datum was taken from a situation involving two pairs of actors acting as a lesbian couple and the parents in a restaurant and a participant. 
A: Marriage is between a man and a woman. I'm not gonna pay for this wedding.

P: I apologize but I think your parents are totally wrong.

(Datum 76)

This couple wants to tell the parents that they are engaged, but surprisingly the parents are against their relationship. They emphasize that marriage is between different genders and force the lesbian couple to break up. Some other customers pay attention to their argument but still stay quiet. However, one of the customers seems to be concerned with what happen to the couple.

When the parents left the scene, this participant approaches the couple and tells them her opinion towards their situation. She shows her support for them by saying that their parents are wrong. However, she does not say that immediately. She apologizes to the couples in the first place. What makes her apologize is because she pays attention to their conversation and actually intervenes in their business.

Following is another example of how the participants use Apologize strategy.

P: Excuse me? I hope you don't mind but can I buy her whatever she wants?

A: We're actually on a budget.

(Datum 82)

This example was taken from a scene where a group of actors act as a mother, a son, and a foster child who went to a restaurant. The mother discriminates the foster child and verbally abuses her. Her action draws attention from some customers in the restaurant. One of them decides to start a conversation with the mother. He offers to buy anything that the foster child wants. He does it politely by saying 'excuse me' at the beginning of his utterance, which is followed by 'I hope you don't mind' before stating his offer. He uses an apology so his utterance would not be too offending and embarrassing the actor. He also uses it to get attention from the actor.

Another example has a supermarket as the setting.
A: Come on, I give hundred bucks not to say anything.

P: No, I mean I can't. I just can't. It's just my level of integrity. I can't. I'm not going to do that to this establishment. I'm sorry.

(Datum 22)

The actor acts as a man who intentionally pours water on the floor and falls to scam the manager. The participant who sees his action wants to tell the manager. The actor offers some money to her to make her not telling the manager. However, she immediately says 'no' and then explains that she cannot take the money. She apologizes to the actor because she cannot accept his request and decides to tell the manager.

The examples illustrate the importance of apologizing to minimize offence to the addressees due to the addressors' interference and refusal. Its significance in negative politeness is also emphasized by Al-Sobh (2013) and Banikalef, Maros, Aladdin and AlNatour (2015).

\section{Give Deference}

An address term is used to show that the speaker is aware of others' face and tries to respect them or be intimate to them. Generally, a formal address term is used in a formal situation or used for addressing someone who is not really close to the speaker, or giving deference. Meanwhile, a more personal address term is used to address known relatives or close friends, or showing intimacy or equality.

Following is the use of address term to show deference among the speakers in an informal situation.

P: Wow! That's incredibly rude.

A: I just wanna make sure these children are safe.

P: Ma'am, I'm so sorry, this is completely inappropriate, if you have an issue can you please leave this restaurant.

(Datum 37)

In this excerpt an actor acts as a black baby sitter while another actor as a white woman who suspects him for being a kidnapper. She repeatedly questions him, 
takes his photo and even asks others to call a police. Most of customers were shocked when they saw her being rude to the baby sitter. She becomes ruder and continues to accuse him. Her action makes one of the target participants in that restaurant expresses her reaction verbally. She started by saying 'wow' to show that she is shocked by her action. Then, she tells the actor that her action is inappropriate. Although she does not like the actor's action, she is still able to pay respect to the actor and call her by using an address term 'Ma'am', which is common among westerners.

The use of address terms to show politeness to some extent is culture specific. Huang (2008) illustrates the use of occupation, which is used as both formal and informal addresses in China but only as formal address among westerners.

\section{Be Pessimistic}

The frequency of Be Pessimistic as a negative politeness strategy in this study shows its sixth rank, which is lower than its rank in both English and Chinese movie reviews in Mu's (2015) study. When applying this strategy, a speaker shows his doubt in delivering his utterance. He also conveys that he does not want to force his thought to be true and to avoid imposing his request to the addressee. It is usually marked by the use of question tag.

A: Would you believe my mom? She didn't actually let me get these.

P: Well, she's buying you something, right?

(Datum 09)

The setting of Datum 9 is a show store. Two actors act as a mother and her son, who wants to buy a pair of sneakers. They started to argue because his mother could not afford the sneakers that he wants. He tries to get some support from other customers in that store and keeps saying that his mother is not giving what he wants. One of them responds to the actor and patiently talks to him. He seems unsure to state his thought because he does not want to threaten the actor's face. He carefully says that his mother is kind because she has bought something for him. He actually tries to say that the actor should respect his mother and be grateful for what he gets. He softens his opinion by applying a question tag.

Following is another example of Be Pessimistic strategy, taken from a scene involving a participant and two actors who act as customers in a grocery store.

A1: Ma'am, I just saw you in the parking lot walking fine so how come you took the cart?

A2: Well, it was available. What do you mean? Ma'am, if you were me wouldn't you taken it?

P: If I had something going on with my legs I suppose, yeah.

(Datum 24)

One of them acts as a truly injured person and the other is faking her injury so she can use the shopping cart. They have a little argument of who should use the cart. One of them asks other customers to help them solve the problem. The customer who decides to help them is aware of the situation, in which one of the actors is lying about her injury so she responds by saying that she will take the cart only if she truly has some injury with her legs. She says this by referring to the actor's fake injury. She wants to say that she agrees with the first actor who really injured her legs without making the other actor feels offended.

\section{State the FTA as General Rule}

Stating the FTA as a general rule means that the speaker does not intentionally threaten the addressee's face but is forced to do it by circumstances like general rule, regulation, or obligation (Brown \& Levinson, 1987). The finding reveals that this strategy is rarely used and this is similarly found by $\mathrm{Mu}$ (2015).

A: You can't find friends who look like someone like you, John? Come on.

P: I don't know what you're thinking you're doing but being an adult, I'm not going to sit in this restaurant and watch you bully people like that.

(Datum 56)

This excerpt shows a situation performed by two groups of actors in a restaurant. One group acts as the bullies while the other group 
acts as the victims. All of them are classmates and one of them is a black girl. They bully the girl because she is black and she befriends with a white boy. This scene draws attention from other customers who are mostly adults. One of them seems uneasy to witness the bullying and jumps into their conversation to stop the bullies. Although she wants to confront them, she is aware of talking to children so she tries to make her utterance as soft as possible without scaring the children. Instead of prohibiting them to bully and embarrass them, she says that she cannot let them do that because she is an adult, who has responsibility to protect children. Her reason to stop them is because she follows the common thing that adults usually do.

Next is another example of this strategy, taken from a conversation between a participant and an actor in a restaurant. The actor, his mother, and his sister come to celebrate his birthday but his mother does not have enough money to buy food for all of them. He insists of buying more food because it is a special day for him.

P: People do that when you order pizza. You know, you order and everybody take a piece.

A: But I'm so hungry.

(Datum 32)

The participant who sees this situation tries to make the boy understand his mother's situation. She explains that they should share the food because others do the same thing when they eat pizza. She makes her suggestion sound like a common rule because she does not want to make the boy more upset. She also says that to help the mother to solve their problem.

\section{Factors affecting the choice of negative politeness strategies in What Would You Do?}

There are two factors affecting the choice of negative politeness strategies: The Payoffs and the circumstances factors (Brown \& Levinson, 1987). The payoffs factor relates to the advantages a speaker will get by applying a particular strategy. Meanwhile, the circumstances factor is about the situations in which the conversations take place such as social distance, social power, and rank of imposition.

\section{The Payoffs}

The Payoffs factor appears most frequently in the data, showing that this intrinsic factor influences common people or the participants in the TV show. Moreover, it also affects the royal family members as found by Pratiwi (2019). Either consciously or unconsciously, many people consider gaining advantages when applying negative politeness strategies but still they do not want to offend others' face and try to avoid embarrassment. Following is the first example from the TV show.

A: I'm not playing charades with right now, what else do you want?

P: Why don't you get somebody else to serve him?

(Datum 28)

The conversation shows an actor acting as a deaf man who wants to dine in a restaurant. Another actor (Datum 28) acts as an impatient waiter who harasses the deaf actor. When the deaf customer wants to place an order using sign language, the waiter seems rude to him because he does not understand what the customer is saying. A lady sitting next to the deaf customer's table notices this scene and watches them silently. Because of the waiter being more impatient towards the customer, she decides to involve in that situation. She patiently helps the man to place his order and talks to the waiter afterwards. She asks him to get another waiter to serve the man by indirectly commanding him to do something and using questions because she does not want the waiter lose his face and being embarrassed.

Next conversation (Datum 42) happens between a grocery store staff and a customer.

A: Then why would you help him?

P: Why would you be absolutely inconsiderate of another human being especially whenever you have to be much younger than him?

(Datum 42) 
The staff is commenting an old man who pays his groceries with coins. The participant helps the man and confronts the staff. The staff asks his motive of helping the man. He directly answers the staff by also asking a question. However, his questions does not likely need any answer from the staff because it points at her rude attitude towards the old man. By using this strategy, the participant is able to show that he disapproves the staff's action and also stops her from continuing her action. Moreover, he is able to maintain the old man's face and saves him from embarrassment.

\section{The Circumstances}

The second factor that affects the choice of negative politeness strategy is the circumstances factor, which is divided into three sub-categories: the social distance, the social power, and the rank of imposition. Giving more evidence to Brown and Levinson's (1987) prediction that power has a negative correlation with politeness, this present study found that social distance is more influential than power in affecting the choice of politeness strategy. This finding is similar to AlAfnan (2014) in the context of email communication in a Malaysian educational institute.

\section{The Social Distance}

The sub-category of social distance relates to the horizontal relationship between the speaker and the addressee based on age, gender, or closeness dimensions.

A: Yes, I cheated on you. You know what, she's more fertile than you are.

P: Are you alright, Ma'am? You're okay? Maybe you shouldn't do this out here in public, Sir. I understand but I'm talking to you. Why don't you calm down, alright?

(Datum 72)

This conversation is performed by a pair of actors acting as husband and wife. The scene shows the husband verbally abusing his wife in a public place. Since he shows a tough character and being very rude to his wife, people who saw his action choose to ignore them and only give a glance because they are afraid to confront the husband. However, one of them carefully approaches them and initiates a conversation to the husband. He intends to protect the wife and separates her from her husband. He addresses the woman as 'Ma'am' and the man as 'Sir'. He uses the address terms because they do not know each other so he tries to respect the distance between them. Besides, the participant is younger than the actors so he tries to show respect them by using formal addresses. The speaker's lower position in term of age and his and the interlocutors' social distance have become factors of the speaker's tendency in choosing negative politeness, supporting one of findings by Jeanyfer and Tanto (2018).

\section{The Social Power}

Different from the social distance, the social power sub-category is a vertical relationship between the interlocutors. Usually, someone who has less power will use a more formal language and negative politeness to someone with higher power.

A: Hey, how you doing? - I don't know, I don't know what you're trying to say. - Man, I don't have time for this.

P: Could you show a little more sensitivity?

(Datum 27)

This interaction takes place between a participant and an actor who acts as a waiter. The waiter is rude to another actor who acts as a deaf customer in a restaurant. The participant, who is also a customer in that place, bravely interrupts the waiter's rudeness to defend the deaf customer. As a customer, she has the right to ask for a good service from the restaurant and has a power to command and request the waiter to do something with the deaf customer. However, she does not bluntly ask him to do so, but uses a particular negative strategy to pay respect to his face.

Another following example shows the influence of this factor.

A: I think this might be get her in.

P: I'll be honest with you, I'm a teacher. They look for, obviously grades but how well rounded you are. I mean I don't think you really need to, but I don't want to go against what your mom is saying, to be honest.

(Datum 70) 
Two actors act as a mother and a daughter in a gym. This mother wants to fake a photo for her daughter's college application. She looks for suggestions from other people in that gym. Most of them come to help her, but they suddenly stop when they know her motive. One of the participants who tries to help is a teacher. Her opinion is quite different from the mother's thought. She believes that the daughter does not need to fake a photo to apply for a university. She wants to suggest that the daughter should not follow her mother's action. However, she is aware that she is a stranger and does not have the right to prohibit them. She even says that she actually does not want to offend the mother despite her different opinion from the mother. Therefore, she adds her occupation as a teacher to her utterance to make the utterance sound convincing and powerful. It shows that she uses her power as someone who is familiar with education topic to forbid what the mother intends to do.

\section{The Rank of Imposition}

This factor is about the lowness or the highness of an imposition to the addressee's face. The bigger the request, the higher the imposition is.

A: Okay, I'm going to put this on because I don't want to catch that.

P: Oh come on. Oh my goodness. Oh my goodness. Stop. Stop. It's a condition. It's a rare condition. That's all about it but her skin is so soft and beautiful. So why don't you come sit over here with us?

(Datum 16)

This example is extracted from a conversation between actors who play roles as a nail salon staff and the customer who has vitiligo. The staff does not want to serve this customer because she is afraid that the vitiligo is infectious. She continually embarrasses the customer for having vitiligo all around her body. Her action makes the customer sitting next to her feel uncomfortable. She suddenly stops the staff and explains that vitiligo is a rare condition. She even shows that it is not infectious by touching the customer's hand. She offers the customer to move from her chair and sit next to her. Her request has a low rank of imposition because the addressee is able to do that although it is requested by someone she does not know. Through the question instead of a direct command, the participant maintains the actor's face and also lets her having choices.

Next is a dialogue showing a situation where an actor acts as a girl who wants to buy a pair of sneakers. However, her father could not buy the one that she wanted. She continually complains about her father to other customers in the store. She even says that her father is embarrassing her.

A: He's embarrassing me. He wants me to put ugly shoes.

P: Why don't you get a job and get them by yourself, okay? So you get a job and you can get them yourself.

(Datum 10)

One of the customers decides to talk to her. She criticizes her for claiming her father embarrassing and tries to persuade her to respect her father. She asks the actor to get a job and buy the shoes by herself instead of forcing her father like she did. She says this to make the actor realizes that she should be grateful that her father still gives something to her and that she should respect her father. This request actually has a high rank of imposition because the addressee is a child who is not able to earn money yet. It is a request that might be hard to be granted by the actor.

The representative data show that even in difficult situations, polite language should still be applied to deliver messages and to maintain social relationship.

\section{Conclusion}

Among the seven types of negative politeness strategies found, Questions, Hedges is the most frequently used by the TV show participants to initiate a conversation to a person they are not familiar with. It is used to maintain the social distance between them and respect the addressee's negative face. The use of questions does not only provide options to the addressee to accept or refuse the speaker's request but also softens their requests or 
commands to the addressee. Meanwhile, the use of hedges will make their utterances sound more polite and shows their hesitancy in delivering their utterances.

With regard to factor, the Payoffs has the highest frequency because it is a basic factor considered by the participants before choosing a particular politeness strategy. The Circumstance factor can be clearly divided into three sub-factors: social distance, social power, and rank of imposition; the circumstances are closely related.

The participants' responses to the actors in What Would You Do? are authentic and reflect how in real life people might speak politely despite being in unexpected situations. In Indonesian context, the participants' authentic verbal actions in this TV show can be used as English as a foreign language (EFL) teaching-learning materials to raise students' sociopragmatic awareness of politeness across languages and cultures. Referring to Haugh and Chang (2015), the English examples of politeness might be compared to the students' L1 or L2 contexts so that they can reflect on the sociopragmatic similarities and differences of politeness in their ambient languages and the learnt foreign language. Such data from the TV show might also be used to make the students recognize, for instance, particular discourse markers to show politeness. As found by Jegarlooei and Allami (2018), there are differences between discourse markers as hedging devices across language. Accordingly, equipping Indonesian EFL students with knowledge of politeness in English is important due to differences across languages and cultures.

\section{References}

AlAfnan, M. A. (2014). Politeness in business writing: The effects of ethnicity and relating factors on email communication. Open Journal of Modern Linguistics, 2014. https://doi.org/10.4236/ojml.2014.4202 2
Al-Sobh, M. A. (2013). An analysis of apology as a politeness strategy expressed by Jordanian university students. International Journal of Humanities and Social Science, 3(2), 150-154. http://www.ijhssnet.com/journals/Vol_3 _No_2_Special_Issue_January_2013/15.pd $\mathrm{f}$

Banikalef, A. A., Maros, M, Aladdin, A \& AlNatour, M. (2015). Apology strategies in Jordanian Arabic. GEMA Online Journal of Language Studies, 15(2), 83-99. https://ejournal.ukm.my/gema/article/v iew/7203

Brown, P., \& Levinson, S. (1987). Politeness: some universal in language use. Trowbridge: Redwood Burn Ltd.

Denzin, N. K. (2009). The Research Act: A Theoretical Introduction to Sociological Methods. London: Routledge.

Fitriyani, S., \& Andriyanti, E. (2020). Teacher and students' politeness strategies in EFL classroom interactions. Indonesian Journal of English Language Teaching and Applied Lingustics, 4(2), 259-273. https://ijeltal.org/index.php/ijeltal/artic le/view/473

Friginal, E., \& Hardy, J. (2014). Corpus-based sociolinguistics: A guide for students. New York: Routledge.

Greene, J. C., Caracelli, V.J., \& Graham, W. F. (1989). Toward a conceptual framework for mixed method evaluation designs. Educational Evaluation and Policy Analysis ,11(3), 255-274.

Haugh, M., \& Chang, W. M. (2015). Understanding im/politeness across culture: an interactional approach to raising socio-pragmatic awareness. IRAL (International Review of Applied Linguistics), 53(4), 389-414.

https://ro.uow.edu.au/cgi/viewcontent.c gi?article $=3226 \&$ context=lhapapers

Holmes, J. (2013). An introduction to sociolinguistics. New York: Longman.

Huang, Y. (2008). Politeness principle in crossculture communication. English Language Teaching, 1(1), 96-101. https://files.eric.ed.gov/fulltext/EJ10825 89.pdf

Jeanyfer, \& Tanto, T. (2018). Request strategies in Indonesia: An analysis of politeness phenomena in text messages. 
Journal of Language and Literature, 18(2), 137-145.

https://ejournal.usd.ac.id/index.php/JOLL/article /view/1569

Jegarlooei, S. H. M., \& Allami, H. (2018). (Im)politeness strategies and use of discourse markers. Cogent Arts and Humanities, 5(1), 1-24.

https://doi.org/10.1080/23311983.2018 .1461048

Lakoff, R. (1975). Language and woman's place. New York: Harper and Row.

Leech, G. N. (1983). Principles of pragmatics. London: Longman.

Leech, G. N. (2005). Politeness: Is there an East-West divide? Journal of Foreign Languages, 6(3), 1-30. https://doi.org /10.1515/PR.2007.009

Mills, S. (2003). Gender and politeness. Cambridge: Cambridge University Press.

Mohammadi, M., \& Tamimi Sa'd, S. H. (2014). Native speakers' assessment of (im)politeness of non-native speakers' requests. International Journal of Research Studies in Language Learning, 3(4), 23-40.

https://doi.org/10.5861/ijrsll.2013.591

$\mathrm{Mu}, \mathrm{Y}$. (2015). The application of politeness strategies in English and Chinese Movie Reviews. International Journal of English Linguistics, 5(6), 105-114. https://doi.org/10.5539/ijel.v5n6p105

Pratiwi, K. (2019). Negative politeness strategies by royal families as portrayed in
British movies (Master's Thesis, Yogyakarta State University).

Ramadhani, P., Gurning, B., \& Sibarani, B. (2014). Politeness strategies and gender differences in Javanese indirect speech acts. Jurnal Linguistik Terapan Pascasarjana Unimed, 11(1), 24-33. https://jurnal.unimed.ac.id/2012/index. php/LTBI/article/view/2672

Redmond, M. (2015). Face and politeness theory. English Technical Reports and White Papers. 2.

https//lib.dr.iastate.edu/engl_reports/2/

Senowarsito. (2013). Politeness strategies in teacher-student interaction in an EFL classroom contents. TEFLIN Journal, 24(1), 82-96.

https://doi.org/10.15639/teflinjournal.v 24i1/82-96

Siffianou, M. (1992). Politeness phenomena in England and Greece. Oxford: Clarendon Press.

Terkourafi, M. (2011). Thank you, Sorry and Please in Cypriot Greek: What happens to politeness markers when they are borrowed across languages?. Journal of Pragmatics, 43(1), 218-235.

https://doi.org/10.1016/j.pragma.2010. $\underline{07.024}$

Vanderstoep, S. W., \& Johnston, D. D. (2009). Research methods for everyday life: Blending qualitative and quantitative approaches. California: Jossey Bass. 